\title{
The First Decade of Economic Transition in Central Asia: An Introduction to the Symposium
}

\section{YELENA KALYUZHNOVA}

The Centre for Euro-Asian Studies, The University of Reading, Whiteknights, P0 Box 218, Reading RG6 6AA, UK. E-mail: y.kaluyzhnova@reading.ac.uk

Comparative Economic Studies (2003) 45, 437-441. doi:10.1057/palgrave.ces.8100034

In the vast existing literature on economics of transition, only relatively few papers concentrate on economic developments in Central Asia (see eg Kaser, 1997a, b; Pomfret, 1995, 2002; Kalyuzhnova, 1998, 2000, 2002). This is probably because of the geographical remoteness of the region from Europe, a lack of easily available statistical data from the national statistical offices and the perception that the Central Asian transition is one of the most turbulent, with authoritarian methods of management and a mentality among the people that is vastly different from the European. Nevertheless, important economic issues have already been raised by Central Asia's economic development, and the attention of international economic organisations has clearly 'shifted' towards Central Asian region (see EBRD, 2003).

In light of the current demand for research evaluating of the impact of economic changes in Central Asia over the last decade, the present symposium is very timely and valuable. 'The Central Asian economies could not follow the rapid approach due to inherited 'regional specifics': a complete absence of previous experience with market institutions, coordination and practice, attitudes of the population as well as the challenge of building new national economies and adapting their economic systems, which were not economic systems themselves, to the new requirements of the transition period.' (Kalyuzhnova, 2000, 166).

The first paper in the symposium is a paper by Pomfret that looks at the combination of the national accounts estimates and household survey results. The author attempts to assess the biases in GDP measures as indicators of economic well-being and ranks the five Central Asian countries' performance in the following order: 'better' - Kazakhstan, the Kyrgyz Republic and 
Uzbekistan and 'worse' Tajikistan and Turkmenistan. The early years of transition saw a sharp decline in most sectors of these economies; however, as Pomfret has pointed out, the significant declines in real GDP overstate the situation due to the fact that the reporting bias shifted from over-reporting in the centrally planned economy to under-reporting in the market economy, and the downward bias after the transition was exacerbated by far from complete coverage of household production and new private enterprises. In addition, "the changing composition of output and the pervasive phenomenon of new and higher quality goods and services meant that the output changes in the early transition years are over-deflated, and the divergence between output and economic welfare exacerbated this under-representation of transition benefits' (see p.).

Nevertheless, the statistical comparison across all these countries, which covers the beginning of transition, demonstrates that every Central Asian country experienced a substantial decrease in GDP and industrial production. (See Figures 1 and 2.)

In Kazakhstan, Kyrgyzstan and Tajikistan, industrial output declined to around 60 percent of the 1991 level, and the recovery was more fragile than for aggregate output. Uzbekistan has had a smaller reduction, with production declining by 31 percent.

This negative performance can be explained by reallocation, namely 'centrally planned economies had too large a manufacturing sector, too small a service sector'. (Blanchard, 1997, 4). However, the specific feature of all Central Asian industries in the pre-transition period has been an orientation towards raw materials in conjunction with substantial agricultural production. This has resulted in an industrial structure in the Central Asian economies where the key parts of the value chain are located in other Republics, the transfer of components along the value chain occurred on a

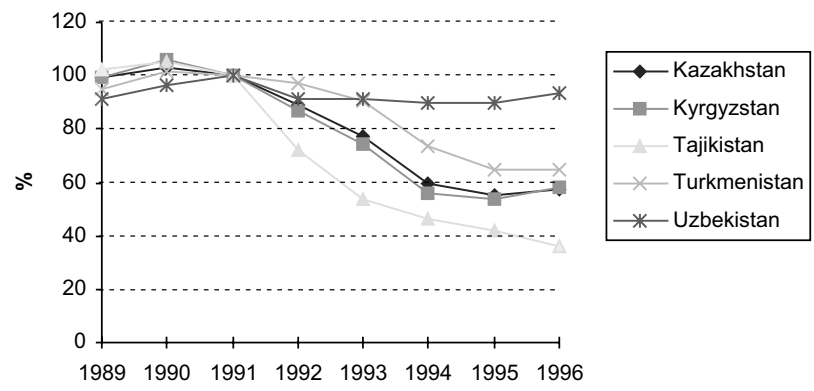

Figure 1: Dynamics of the GDP changes in the five Central Asian Countries, Indices 1991=100\% (1989-1996). Source: This figure was drawn on data from the EIU, Uzbekistan Country Report, 4th quarter 1997. 


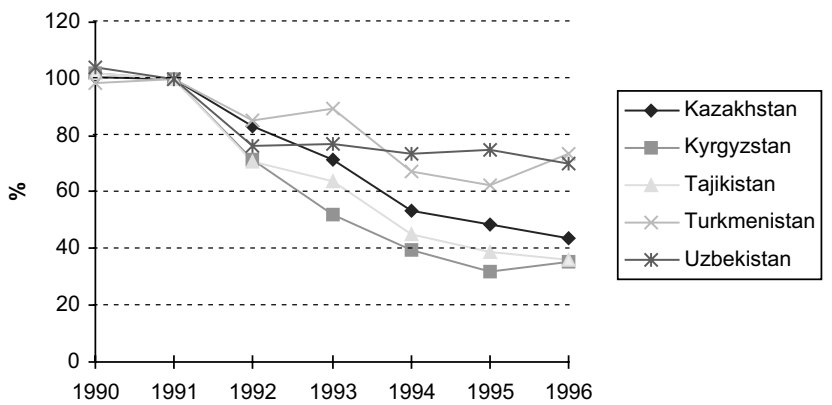

Figure 2: Central Asian Economies: Industrial output (percentage of change, 1991=100\%) (1990-1996). Source: This figure is based on data from REUTERS Business briefing, November 3, 1997, Economic Survey of Europe in 1996-1997, Ekonomika Stran Sodruzhestva Nezavisimykh Gosudarstv v 1994, Kalyuzhnova, (1998) The Kazakhstani Economy: Independence and Transition, Statisticheskii Yezhegodnik Kazakhstana 1991, 1993, 1995, 1996, 1997; as well as estimates by the Centre for Euro-Asian Studies (Reading, UK) and the author.

non-price-orientated basis, and inter-enterprise links often involved complicated and long-term relationships, which are now proving particularly problematic to unravel.

Indeed, the transition period covers completely new ground for all Central Asian economies: both in macro- and micro-terms, both in the depth and the width of the market transformation. In addressing this economic transformation of the employment and the labour market, these changes mean, as a consequence of closing down unprofitable enterprises, the end of the guaranteed employment system (at least theoretically), which all Central Asian countries enjoyed prior to transition. Both papers by Kalyuzhnova, Vagliasindi, and Casson and Babetski, Kolev and Maurel look at the challenges of the Kazakhstani and Kyrgyz labour markets. In 1998-1999, the Central Asian transition has been impacted by Asian and Russian crises and low world prices on oil and gas.

The paper by Kalyuzhnova, Vagliasindi and Casson examines the employment changes during this turbulent time in Kazakhstan. Based on a survey of 701 Kazakhstani firms, the authors tested by cross-section regressions, the theoretical propositions of the employment behaviour of firms in transitional economies. The paper finds that changes in ownership per se did not cause a significant difference in the behaviour of newly privatised enterprises in Kazakhstan. Nevertheless, the paper does provide some evidence of a differential effect of privatisation on export-oriented enterprises, which is particularly pronounced in the contraction for the Central Asian economies during the two financial crises. This supports the conclusion that once subsidisation was either stopped or reduced significantly, the privatisation and restructuring took place and there was a positive 
effect on employment. There is also evidence of upward employment adjustments in response to price increases and input price decreases, as well as in response to time and regional dummies reflecting the different stage of recovery from the Russian crisis.

Without doubt, the analysis of the dynamics of employment during the transition period is closely connected with the impact of privatisation. However, as Babetski, Kolev and Maurel found, it is very early to state that the private sector has already become an instrument for job creation. The paper brings together the analysis by reviewing Kyrgyz labour market development during the first decade of transition with particular reference to the nature of labour market restructuring and job reallocation. The authors confirm that setbacks in the Kyrgyz privatisation process have revealed weaknesses in the privatisation strategy of medium-sized and large enterprises and, more importantly, affected the process of restructuring, which is unable to provide the basis for the country's poverty alleviation strategy and job creation.

In addition to the economic obstacles and specifics of the Central Asian region discussed in the previous papers, the final paper in the Symposium by Raballand highlights the impact of, perhaps, the most common feature of all Central Asian countries - the land-lockedness of the region. The author tested the impact of land-lockedness on trade by using four measures, namely: trade relations between two land-locked countries; the shortest distance between land-locked country and the nearest major port facilities; the number of borders with costal countries; and the number of national borders crossed. The robustness of the econometric results confirmed that being land-locked the Central Asian countries experience a major negative effect on their trade. Upon independence, each of the Soviet successor states was 'responsible' for a certain pattern of inter-Soviet production and trade (Tarr, 1994; Webber, 1997), and of course resource allocation decisions were based on the Soviet (not republican) transport costs. As examined in the paper, in the Soviet period the transportation was never a cost factor. This had a negative impact on trade after 1990 .

Overall, as papers of the symposium highlighted, the scale and regional diversity of the Central Asian market has made transition a particularly complex case. After the dissolution of the Soviet Union, the Central Asian economies found themselves in an incredibly difficult position - the challenge of major structural transformation in industrial sectors has arisen for all Central Asian countries, which were previously a part of the planned economy of the entire Soviet Union. The imbalances that appeared in the new national economies was supposed to be counterbalanced by governmental actions, but the authoritarian Central Asian management style failed to 
provide this support. Nevertheless, as the authors found out, reality brought its own corrections in terms of the dynamics of the impact of privatisation, labour market adjustments, etc. Moreover, increasing disintegration of the economic links between Central Asian states, conversely, highlighted their interdependence. 'In the early 1990s, the top priority for the new independent states was to try to maintain existing trade links in order to security of input supplies and of markets.' (Pomfret, 2000, 193). In this respect, being landlocked is one of the most important, but inescapable, negative factors for the economic future for all Central Asian countries.

\section{REFERENCES}

Blanchard, O. 1997: The economics of the post-communist transition. Clarendon Press: Oxford. EBRD. 2003: Annual Meeting. Working Materials. www.ebrd.com/am.htm.

Kalyuzhnova, Y. 1998: The Kazakstani economy: Independence and transition. Macmillan: London.

Kalyuzhnova, Y. 2000: The economic transition in Kazakhstan and Uzbekistan. In: Kalyuzhnova, Y and Lynch, D (eds). The Euro-Asian World: A Period of Transition, Chapter 9. Macmillan Press: New York.

Kalyuzhnova, Y. 2002: Economies and energy. In: Kalyuzhnova, Y, Jaffe, AM, Lynch, D and Sickles, R (eds). Energy in the Caspian Region: Present and Future, Chapter 3. Palgrave: New York.

Kaser, M. 1997a: The Central Asian economies. In: Economic Survey of Europe 1996-1997. ECE/UN: Geneva.

Kaser, M. 1997b: The economies of Kazakstan and Uzbekistan. The Royal Institute of International Affairs: London.

Pomfret, R. 1995: The economies of Central Asia. Princeton University Press: Princeton, NJ.

Pomfret, R. 2000: Central Asian regional integration and new trade patterns. In: Kalyuzhnova, Y and Lynch D (eds). The Euro-Asian World: A Period of Transition, Chapter 10. Macmillan Press: New York.

Pomfret, R. 2002: Constructing a market economy: Diverse paths from central planning in Asia and Europe. Edward Elgar: Cheltenham, UK/Northampton, MA, USA.

Tarr, D. 1994: How moving to world prices affects the terms of trade of 15 countries of the former Soviet Union. Journal of Comparative Economics 18: 1-24.

Webber, M. 1997: CIS Integration Trends: Russia and the Former Soviet South. The Royal Institute of International Affairs: London. 